\title{
ロボットアームの強度的危険性を回避する動作計画法*
}

\author{
磯部 大吾郎 ${ }^{* 1}$, 山口 良規 ${ }^{* 2}$
}

\section{A Motion Planning Scheme to Avoid Structural Damage of Robotic Arms}

\author{
Daigoro ISOBE ${ }^{* 1}$ and Yoshiki YAMAGUCHI
}

${ }^{* 1}$ Division of Engineering Mechanics and Energy, Univ. of Tsukuba

1-1-1 Tennodai Tsukuba-shi, Ibaraki 305-8573, Japan

\begin{abstract}
A motion-planning scheme that enables robotic arms to avoid structural damage is developed by implementing risk determination and motion modification algorithms in a finite element code. The scheme searches safer motion of robotic arms when their structural risk determined by a function of sectional forces becomes higher than a threshold during their given tasks. The safer motion is achieved by decreasing the total strain energy stored in the structure of the robot. Some examples of motion modification are demonstrated by giving lift-up and lateral carrying tasks to a robotic arm, where the achieved motions are compared by varying the structural parameters. Furthermore, the proposed scheme is implemented in an interface of a robotic arm to verify its applicability and practicability in actual motion control.
\end{abstract}

Key Words : Motion Planning, Robotic Arms, Structural Damage, Finite Element Method

\section{1. 緒言}

人間社会との接点が増すにつれ，ロボット機構には安全性がさらに求められるようになった。 その一つの対策 として機構の軽量化が挙げられ，材料やエネルギーコストの観点からもこの方向性は重要視される.しかしその 一方では，軽量化に伴い部材強度が低下し，過度の外力に対し部材破損の危険性が高まることに注意しなければ ならない，ロボット機構の姿勢決定および動作計画については，従来から様々な議論がされており，可操作度に

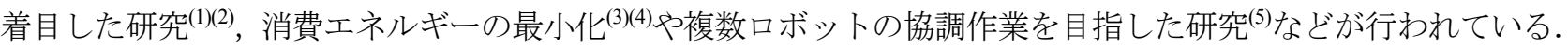
これらの研究では，一般的にロボットの構成部材を剛体とみなし，損壊しないことを前提としており，部材強度 を考慮した姿勢決定や動作計画は実施されていない.

本研究では，ロボット機構の中でも特にロボットアームに着目し，その構成部材の強度的危険性を回避した動 作計画を行うことを目的とする．動作計画では，アームが動作する際に構成部材に発生する曲げモーメントや軸 力などの断面力を監視し, それらがある閾值を超えた場合に安全な方向へ姿勢を変更する. 先行研究 ${ }^{(6)(7)}$ において は，部材の強度的危険性を断面力レベルでの降伏関数を用いて判定し，機構内に蓄積される全ひずみエネルギー を抑制することで安全な姿勢を求めた。しかしその際に，ステップ毎に静的解析を行っていたために慣性項が含 まれず，高速動作には適用できなかった．また，強度的危険回避を優先させていたため，タスクによってはその 達成が困難となる場合があり，実用性に欠けていた。そこで本研究では，アームの高速動作に対応させるために 慣性項を導入した運動方程式を解く過程を加えた。さらに，タスクの実現性を高めるために，タスク未達成時に 補助的に多くの関節を動かすことで全ひずみエネルギーを減少させる過程を加えた。この動作計画法をロボット アームの持ち運びタスクに適用し，危険性の判定に用いる閾值や全ひずみエネルギーの抑制目標值が動作そのも のに与える影響について調べた。また，動作計画法を実機に搭載して実験を行った.

本稿では, 続く第 2 章でロボットアームのモデル化に用いた有限要素の概要および軌道の算出過程について述

\footnotetext{
* 原稿受付 2012 年 4 月 9 日

${ }^{* 1}$ 正員, 筑波大学 システム情報系 構造エネルギー工学域（テ305-8573 茨城県つくば市天王台 1-1-1）

*2 ヒロセ電機(株)（元 筑波大学大学院）

E-mail: isobe@kz.tsukuba.ac.jp
} 
ベ，第 3 章では，開発した動作計画法について解説する．第 4 章では，3 リンク系のロボットアームに荷物の持 ち上げタスクを与えた場合および水平持ち運びタスクを与えた場合について，断面力や全ひずみエネルギーとい ったパラメータが動作計画に与える影響について考察する. 第 5 章では, 開発した動作計画法を市販のロボット アームに実装し，実験を行った結果について検証する．第6 章では結言を述べる.

\section{2. ロボットアームのモデル化および動作軌道の算出}

ロボットアームのモデル化には, Bernoulli-Euler の仮定に基づく 3 次はり要素を用いた. この有限要素は, 断面 剛を仮定するためせん断変形を表現できないものの, 変位関数に 3 次関数が用いられるために曲げ変形に対する 精度が良く, 低次の振動モードに限っては 1 リンク部材当り 1 要素の分割で十分にモデル化が可能である. その ため, リアルタイム制御に適用する際の高速計算には好都合である.さらに，変位関数と同等に質量が分布する ものとして定式化された分布質量マトリックスを用いれば, 振動挙動時の精度も維持される(8)(9). 分布質量マトリ ックスを用いる場合には，リンク部材の重心を改めて表現する必要がないという利点も存在する. 本章では, Bernoulli-Euler の仮定に基づく 3 次はり要素について解説し, 次にアームの動作軌道の算出過程について述べる.

\section{$2 \cdot 13$ 次はり要素の概要}

Bernoulli-Euler の仮定に基づく 3 次はり要素は，次の増分型仮想仕事の式に基づいて定式化される.

$$
\delta V-\delta W=\int\left(\Delta M_{x} \delta \Delta \kappa_{x}+\Delta M_{y} \delta \Delta \kappa_{y}+\Delta N \delta \Delta \varepsilon_{z}+\Delta M_{z} \delta \Delta \theta_{z, z}\right) d z-\delta W=0
$$

ここで，Vおよび $W$ はそれぞれ内部仕事，および外部仕事である. $M_{x}, M_{y}, N$ および $M_{z}$ はそれぞれ， $x$ 軸回り， $y$ 軸回りの曲げモーメント, 軸力, およびねじりモーメントである. 一方, $\kappa_{x}, \kappa_{y}, \varepsilon_{z}$ および $\theta_{z, z}$ は対応する一般 化ひずみである．添字が小文字であるのは，これらが要素座標系による表示であることを示す．座標系と自由度 の定義を図 1 に示す. 以後, 添字が小文字の場合は要素座標系表示, 大文字の場合は全体座標系表示と区別する. 記号 $\delta$ および $\Delta$ は，それぞれ変分，増分を意味する，一般化ひずみの増分は次式により与えられる.

$$
\Delta \kappa_{x}=\frac{d^{2} \Delta v}{d z^{2}}, \Delta \kappa_{y}=\frac{d^{2} \Delta u}{d z^{2}}, \Delta \varepsilon_{z}=\frac{d \Delta w}{d z}, \Delta \theta_{z, z}=\frac{d \Delta \theta_{z}}{d z}
$$

以後, $u, v, w, \theta_{x}, \theta_{y}$, および $\theta_{z}$ は図 1 で定義された変位成分である. 寸なわち, 1 節点当り並進方向 3 自由度 および回転方向 3 自由度の成分によって変位が定義される.

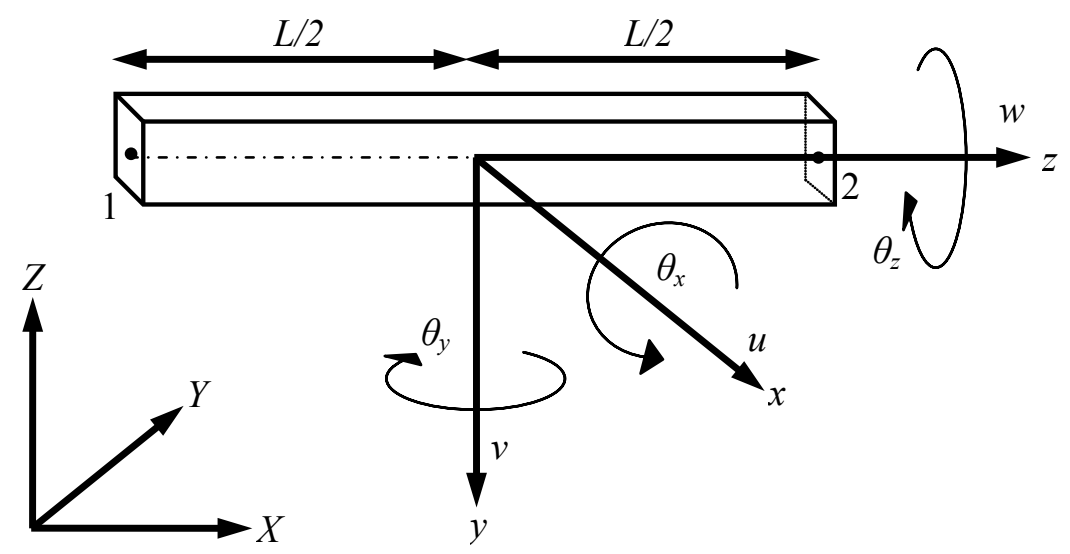

Fig. 1 Definitions of coordinates and displacements 
3 次はり要素では, 次式に示すように横たわみに対して 3 次内挿関数を仮定し，軸方向およびねじれ角に関し ては線形内挿関数を仮定する.

$$
\begin{aligned}
& u(z)=H_{00} u_{1}+H_{10} L \theta_{y 1}+H_{01} u_{2}+H_{11} L \theta_{y 2} \\
& v(z)=H_{00} v_{1}-H_{10} L \theta_{x 1}+H_{01} v_{2}-H_{11} L \theta_{x 2} \\
& w(z)=\frac{1}{2}(1-s) w_{1}+\frac{1}{2}(1+s) w_{2} \\
& \theta_{z}(z)=\frac{1}{2}(1-s) \theta_{z 1}+\frac{1}{2}(1+s) \theta_{z 2}
\end{aligned}
$$

ここで,

$$
H_{00}=\frac{1}{8}\left(4-6 s+2 s^{2}\right), H_{10}=\frac{1}{8}\left(1-s-s^{2}+s^{3}\right), \quad H_{01}=\frac{1}{8}\left(4+6 s-2 s^{2}\right), \quad H_{11}=\frac{1}{8}\left(-1-s+s^{2}+s^{3}\right)
$$

式(3)において, 添字 1 および 2 は図 1 に示される節点番号を意味する．Lは要素長， $s$ は $z /(L / 2)$ と定義される無 次元座標系であり, -1 と 1 の間の值をとる. 式(3)を式(2)に代入すると, 一般化ひずみ増分と節点変位増分の間の 関係が次のように得られる.

$$
\{\Delta \varepsilon\}=[B]\{\Delta u\}
$$

ここで，[B]は一般化ひずみ一節点変位マトリックスである．上式の成分は，具体的には次式のようになる．

$$
\begin{aligned}
& \Delta \kappa_{x}=\frac{6 s_{i}}{L^{2}} \Delta v_{1}-\frac{3 s_{i}-1}{L} \Delta \theta_{x 1}-\frac{6 s_{i}}{L^{2}} \Delta v_{2}-\frac{3 s_{i}+1}{L} \Delta \theta_{x 2} \\
& \Delta \kappa_{y}=\frac{6 s_{i}}{L^{2}} \Delta u_{1}+\frac{3 s_{i}-1}{L} \Delta \theta_{y i}-\frac{6 s_{i}}{L^{2}} \Delta u_{2}+\frac{3 s_{i}+1}{L} \Delta \theta_{y 2} \\
& \Delta \varepsilon_{z}=\frac{1}{L}\left(\Delta w_{2}-\Delta w_{1}\right) \\
& \Delta \theta_{z, z}=\frac{1}{L}\left(\Delta \theta_{z 2}-\Delta \theta_{z 1}\right)
\end{aligned}
$$

ここで，曲率 $\kappa_{x}$ および $\kappa_{y}$ は，剛性マトリックスを 2 点積分により評価することに対応して， 2 点 $s_{1}$ および $s_{2}$ で評 価される. 要素の全領域が弹性的に挙動するときは, ガウス積分点 $\left(s_{i}= \pm 1 / \sqrt{3}\right)$ が最適な数值積分点位置である. 弾性変形時の断面力と一般化ひずみの間の増分関係は, 次式により与えられる. 


$$
\{\Delta \sigma\}=[D]\{\Delta \varepsilon\}
$$

ここで， $[D]$ は断面力一一般化ひずみマトリックスである，上式の成分は，具体的には次式により与えられる.

$$
\Delta M_{x}=E I_{x} \Delta \kappa_{x}, \Delta M_{y}=E I_{y} \Delta \kappa_{y}, \Delta N=E A \Delta \varepsilon_{z}, \Delta M_{z}=G K \Delta \theta_{z, z}
$$

ここで，EI $I_{x}, E I_{y}, E A$ および $G K$ はそれぞれ $x$ 軸回り, $y$ 軸回りの曲げ岡性，軸剛性および Saint-Venant のねじり 剛性である. 式(6)および式(8)より, 要素内の断面力増分は次式のように表される.

$$
\begin{aligned}
& \Delta M_{x}=E I_{x}\left(\frac{6 s_{i}}{L^{2}} \Delta v_{1}-\frac{3 s_{i}-1}{L} \Delta \theta_{x 1}-\frac{6 s_{i}}{L^{2}} \Delta v_{2}-\frac{3 s_{i}+1}{L} \Delta \theta_{x 2}\right) \\
& \Delta M_{y}=E I_{y}\left(\frac{6 s_{i}}{L^{2}} \Delta u_{1}+\frac{3 s_{i}-1}{L} \Delta \theta_{y i}-\frac{6 s_{i}}{L^{2}} \Delta u_{2}+\frac{3 s_{i}+1}{L} \Delta \theta_{y 2}\right) \\
& \Delta N=E A \frac{\Delta w_{2}-\Delta w_{1}}{L} \\
& \Delta M_{z}=G K \frac{\Delta \theta_{z 2}-\Delta \theta_{z 1}}{L}
\end{aligned}
$$

断面力の総計值は，上式をステップごとに足し込むことで算出される，一方，3 次はり要素の分布質量マトリッ クスはその変位関数に基づいて定式化され, 次式のように表現される.

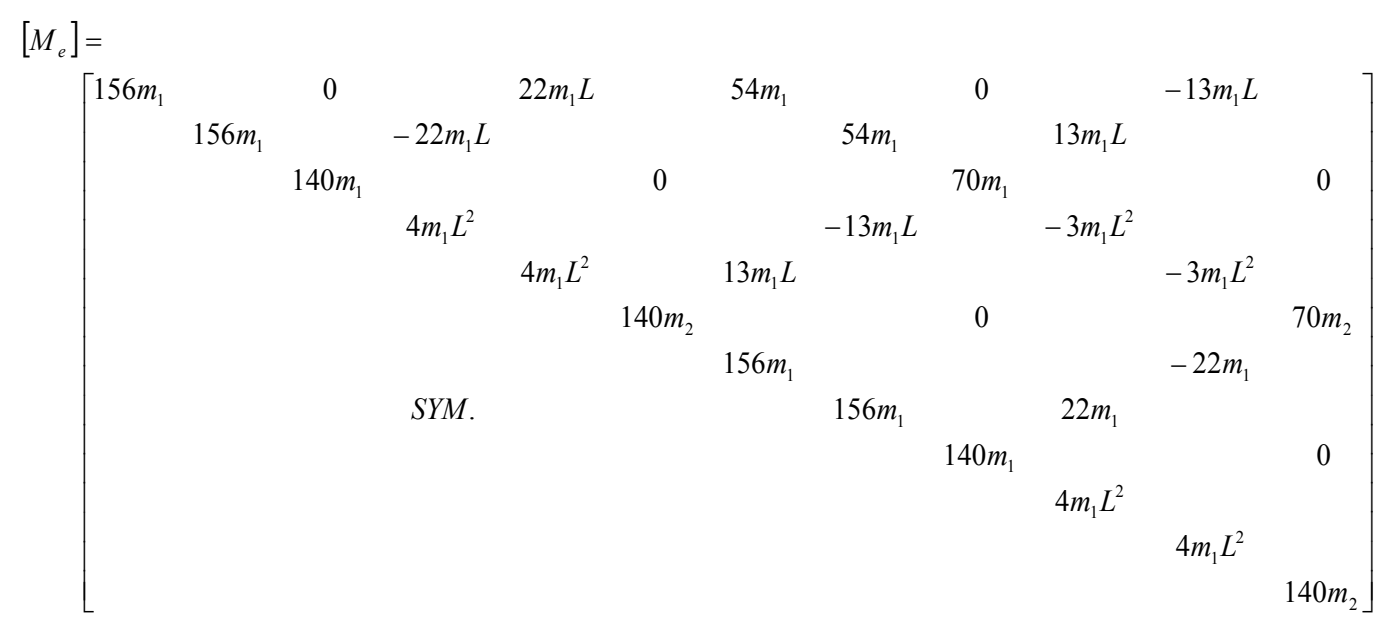

ただし，

$$
m_{1}=\frac{\rho A L}{420}, m_{2}=\frac{\rho I_{z} L}{420}
$$


ここで， $\rho ， A ， L ， I_{z}$ はそれぞれリンクの密度, 断面積, 要素長, 断面 2 次極モーメントである. 有限要素解析 においては，この分布質量マトリックスを用いることで少数の要素分割数でも曲げ応答精度が向上することが知 られている，そこで本研究では，計算時間の短縮および精度向上のために分布質量マトリックスを採用した．な お，関節での付加質量は，全体質量マトリックスの該当する並進方向自由度成分に付加することで与えている.

\section{$2 \cdot 2$ 動作軌道の算出過程}

機構の動作によって生じる慣性項を導入すると，仮想仕事の原理より時刻 $t+\Delta t$ における増分型運動方程式は 次式のように定式化される ${ }^{(10)}$.

$$
[M]\left\{\ddot{u}_{m}\right\}_{t+\Delta t}+[M]\left\{\ddot{u}_{d}\right\}_{t+\Delta t}+[C]\left\{\dot{u}_{d}\right\}_{t+\Delta t}+[K]\left\{\Delta u_{d}\right\}=\{F\}_{t+\Delta t}-\{R\}_{t}
$$

ここで, $[M]$ は全体質量マトリックス, $[C]$ は全体減衰マトリックス, $[K]$ は全体剛性マトリックス, $\{F\}$ は外力ベ クトル, $\{R\}$ は内力ベクトルである. 各要素の質量マトリックスは前節の式(10)より, 剛性マトリックスは次式よ り算出する.

$$
\left[K_{e}\right]=\int_{V}[B]^{T}[D][B] d V
$$

減衰マトリックスには次式に示寸レーリー比例減衰を用いた。

$$
\left[C_{e}\right]=\alpha\left[M_{e}\right]+\beta\left[K_{e}\right]
$$

ここで， $\alpha$ と $\beta$ は減衰定数であり，リンクごとに自由振動時の変位測定実験を行い決定した．なお，これらの要 素毎のマトリックスを適切な個所に足し込むことで, 式(12)に使用する全体マトリックスを構成する.

さらに，式(12)の $\left\{\ddot{u}_{m}\right\}$ はリンクの動作による節点加速度ベクトル， $\left\{\ddot{u}_{d}\right\},\left\{\dot{u}_{d}\right\},\left\{\Delta u_{d}\right\}$ は各々リンクの変形によ る節点加速度ベクトル, 節点速度ベクトル, 変形量増分ベクトルである. Newmark $の \beta$ 法 $(\delta=1 / 2$ と設定）を用 いると，節点加速度ベクトルおよび節点速度ベクトルは次式により計算される.

$$
\begin{aligned}
& \left\{\ddot{u}_{m}\right\}_{t+\Delta t}=\frac{1}{\beta \Delta t^{2}}\left\{\Delta u_{m}\right\}-\frac{1}{\beta \Delta t}\left\{\dot{u}_{m}\right\}_{t}-\left(\frac{1}{2 \beta}-1\right)\left\{\ddot{u}_{m}\right\}_{t} \\
& \left\{\ddot{u}_{d}\right\}_{t+\Delta t}=\frac{1}{\beta \Delta t^{2}}\left\{\Delta u_{d}\right\}-\frac{1}{\beta \Delta t}\left\{\dot{u}_{d}\right\}_{t}-\left(\frac{1}{2 \beta}-1\right)\left\{\ddot{u}_{d}\right\}_{t} \\
& \left\{\dot{u}_{m}\right\}_{t+\Delta t}=\frac{1}{2 \beta \Delta t}\left\{\Delta u_{m}\right\}-\left(\frac{1}{2 \beta}-1\right)\left\{\dot{u}_{m}\right\}_{t}-\left(\frac{1-4 \beta}{4 \beta}\right)\left\{\ddot{u}_{m}\right\}_{t} \Delta t \\
& \left\{\dot{u}_{d}\right\}_{t+\Delta t}=\frac{1}{2 \beta \Delta t}\left\{\Delta u_{d}\right\}-\left(\frac{1}{2 \beta}-1\right)\left\{\dot{u}_{d}\right\}_{t}-\left(\frac{1-4 \beta}{4 \beta}\right)\left\{\ddot{u}_{d}\right\}_{t} \Delta t
\end{aligned}
$$

ここで, $\left\{\dot{u}_{m}\right\}$ はリンクの動作による節点速度ベクトル, $\left\{\Delta u_{m}\right\}$ はリンクの動作量増分ベクトルである. 式(15)を式(12) に代入すると, 次式が得られる.

$$
\begin{aligned}
&\left([K]+\frac{1}{\beta \Delta t^{2}}[M]+\right.\left.\frac{1}{2 \beta \Delta t}[C]\right)\left\{\Delta u_{d}\right\}=\{F\}_{t+\Delta t}-\{R\}_{t}+[M]\left(\frac{1}{\beta \Delta t}\left\{\dot{u}_{d}\right\}_{t}+\left(\frac{1}{2 \beta}-1\right)\left\{\ddot{u}_{d}\right\}_{t}\right) \\
&-[M]\left(\frac{1}{\beta \Delta t^{2}}\left\{\Delta u_{m}\right\}-\frac{1}{\beta \Delta t}\left\{\dot{u}_{m}\right\}_{t}-\left(\frac{1}{2 \beta}-1\right)\left\{\ddot{u}_{m}\right\}_{t}\right)+[C]\left(\left(\frac{1}{2 \beta}-1\right)\left\{\dot{u}_{d}\right\}_{t}+\left(\frac{1-4 \beta}{4 \beta}\right)\left\{\ddot{u}_{d}\right\}_{t} \Delta t\right)
\end{aligned}
$$


上式に $\left\{\Delta u_{m}\right\}$ を目標軌道として入力し，時刻 $t$ における式(15)を逐次的に代入すると，各ステップにおける $\left\{\Delta u_{d}\right\} か ゙$ 求まる. 部材内に発生する曲げモーメントや軸力などの断面力の増分值は, はり理論にしたがって $\left\{\Delta u_{d}\right\}$ より求め られる.さらに, 動作量ベクトル $\left\{u_{m}\right\}$ および変形量ベクトル $\left\{u_{d}\right\}$ は, 次式に従って総和として求められる.

$$
\begin{aligned}
& \left\{u_{m}\right\}_{t+\Delta t}=\left\{u_{m}\right\}_{t}+\left\{\Delta u_{m}\right\} \\
& \left\{u_{d}\right\}_{t+\Delta t}=\left\{u_{d}\right\}_{t}+\left\{\Delta u_{d}\right\}
\end{aligned}
$$

総変位量 $\{u\}$ は, 式(17)で求めた動作量と変形量を足し合わせることによって以下のように求められる.

$$
\{u\}_{t+\Delta t}=\left\{u_{m}\right\}_{t+\Delta t}+\left\{u_{d}\right\}_{t+\Delta t}
$$

上式は，慣性，剛性および減衰を考慮した軌道となる.

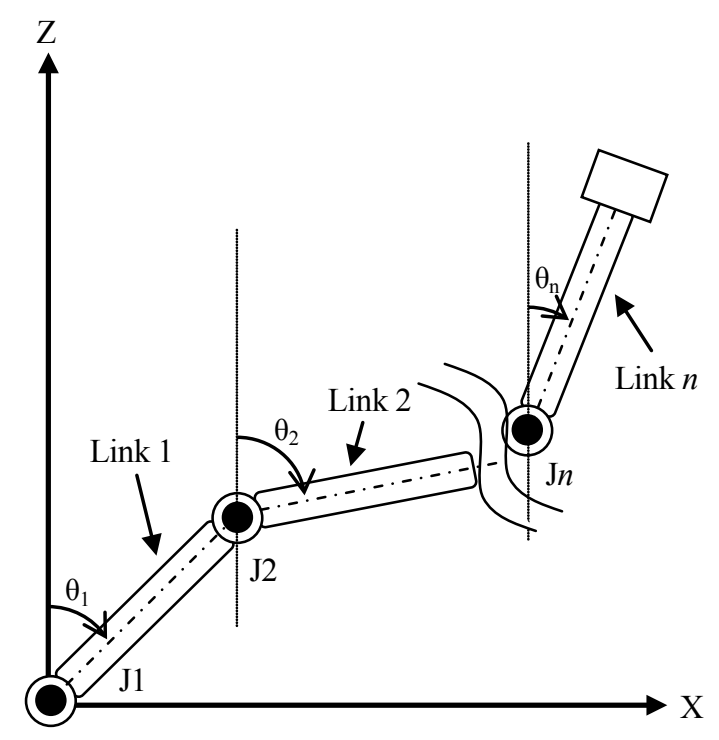

Fig. 2 Joint angles of a robotic arm

\section{3. 部材の強度的危険性を回避する動作計画法}

図 2 に示すような $n$ リンクを有するロボットアームを動作させることを考える．関節を根元から $\mathrm{J} 1, \mathrm{~J} 2, \cdots, \mathrm{J} n$ とし，リンクを根元から Link 1 , Link $2, \cdots$, Link $n$ とする. このとき, 各関節の回転角を $\theta_{1}, \theta_{2}, \cdots, \theta_{n}$ だけ動かし， 所定の位置まで動かすことでタスクを達成する.

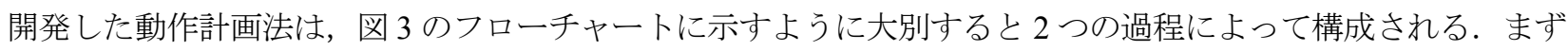
1 つ目の過程では，軌道生成と危険性判定を行う。ここでは，入力した回転角増分に基づき，初期の目標軌道を 作成する. そして，この軌道を前節で示した運動方程式に入力し，慣性や剛性などを考慮した軌道とともに部材 内に発生する断面力を求める. 求められた断面力を以下の降伏関数に入力することで, 時々刻々の部材の降伏危 険性を評価する。

$$
f_{y}=\left(\frac{M_{x}}{M_{x 0}}\right)^{2}+\left(\frac{M_{y}}{M_{y 0}}\right)^{2}+\left(\frac{N}{N_{0}}\right)^{2}
$$




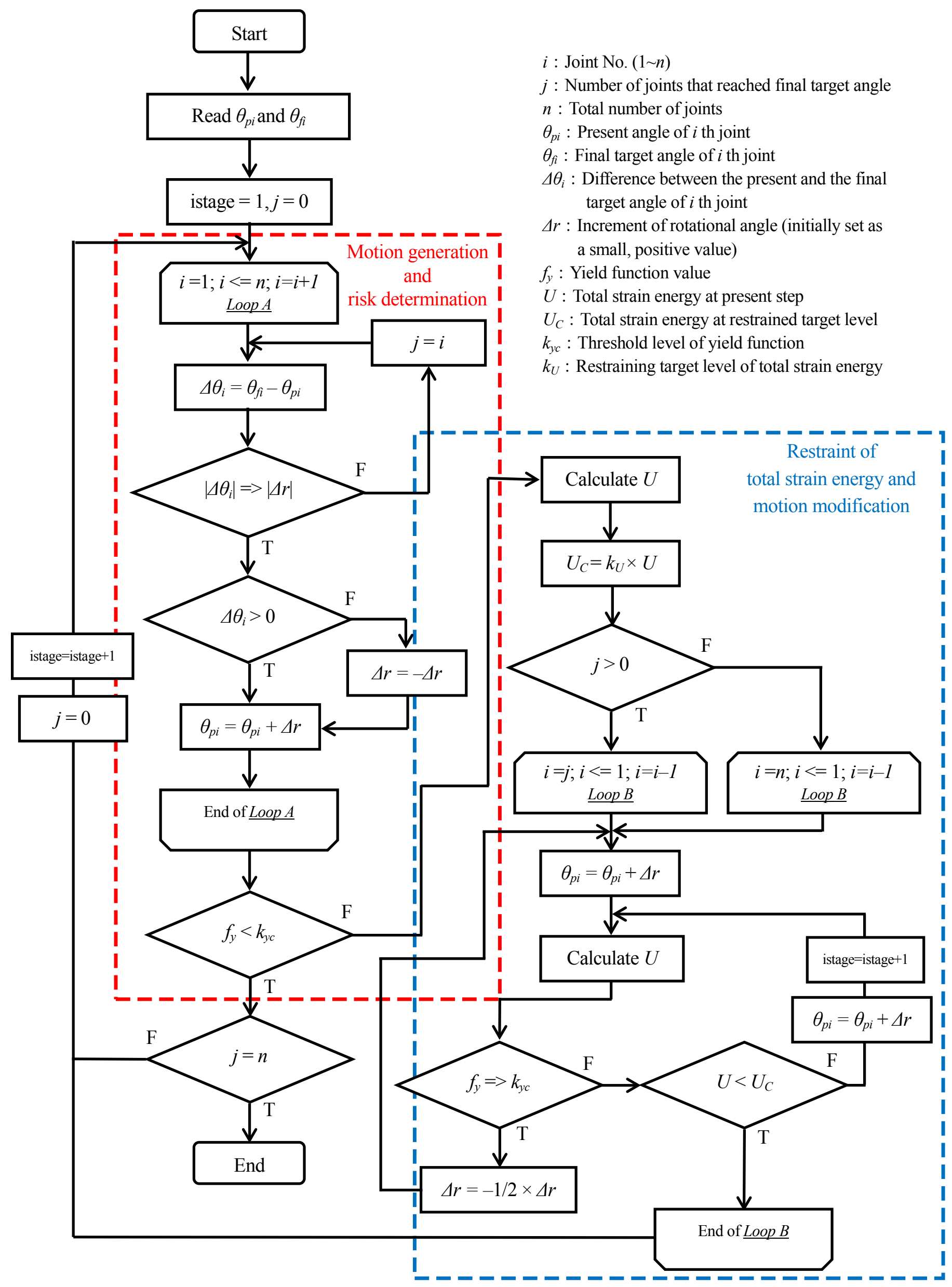

Fig. 3 Flow chart of motion planning avoiding structural damage risk 
ここで, $M_{x}, M_{y}, N$ はそれぞれ要素座標系 $x, y$ 軸回りの曲げモーメントおよび軸力である. 各項の分母は, 各々 の断面力が部材断面に単独で作用した場合の全断面塑性值である. 式(19)よりリンク部材ごとに降伏関数值を求 め, その值があらかじめ設定された降伏危険性判定レベル $k_{y c}\left(0 \leqq k_{y c} \leqq 1\right)$ を超えると, そのリンク部材の強度的 危険性が高まったこととして, 姿勢変更過程へと移る.この值が小さいと危険判定の頻度が増し, 部材の強度的 危険性は減少するが, 当初のタスクの達成が困難となる可能性は高まる. 一方, この值が大きいと危険判定の頻 度は減るが，実際に部材が破損してしまう危険性は高まる．部材ごとの降伏関数值が降伏危険性判定レベルを超 えない限り, リンク系は初期の軌道通りに動作を行う.

1 つ目の過程で危険判定された場合にのみ 2 つ目の過程に入り，そこでは系全体の全ひずみエネルギーを抑制 する方向へ姿勢変更を行う。ここで，全ひずみエネルギーを抑制対象とするのは，系全体の負担緩和を目指して いることと, エネルギー効率の観点からも適切であると判断したためである(7). 系内に蓄積される全ひずみエネ ルギーは, 以下の式で求められる.

$$
U=\int_{V}\{\varepsilon\}^{T}\{\sigma\} d V=\sum_{i e l m=1}^{n e l m}\{\varepsilon\}_{i e l m}^{T}\{\sigma\}_{\text {ielm }} l_{\text {ielm }}
$$

ここで, ielm, nelm, $\{\varepsilon\}_{i e l m},\{\sigma\}_{i e l m}$ および $l_{i e l m}$ はそれぞれ, 要素番号, 総要素数, ielm 番目の要素のひずみべク トル，断面力ベクトルおよび要素長である。式(20)より時々刻々の全ひずみエネルギ一值を求め，危険判定時の 值に対する抑制目標レベル $k_{U}\left(0 \leqq k_{U} \leqq 1\right)$ に達するまで姿勢を変更する. この值が大きいと早めに姿勢変更は終了 するが，1つ目の過程に戻った際に危険判定の頻度が増す可能性は高い. 逆にこの值が小さいと, 大きく姿勢変 更が行われ，その後の危険判定の頻度は減少寸る．なお，系内のリンク部材で危険判定されると，効率性の観点 から先端側の関節から順に動作させて全ひずみエネルギーの抑制を図ることとし，その際の関節の回転方向は， より全ひずみエネルギーを大きく抑制させる方向と定める．また，全ての関節が最終目標角に達していない場合 には，補助的に第 2，第3の関節を動かし全ひずみエネルギー值を減少させることとした.

\section{4. 動作計画法の適用例}

本章では，前章で示した動作計画法をロボットアームの鉛直持ち上げ動作および氷平持ち運び動作に適用し， 降伏危険性判定レベルや抑制目標レベルなどのパラメータが動作計画に及ぼす影響について考察する.

\section{$4 \cdot 1$ 鉛直持ち上げ動作への適用例}

3 リンクのロボットアームを用い，鉛直下向きから上向きまで持ち上げ動作を行う．ロボットアームの概形お よび初期の目標軌道を図 4 に, ロボットアームの部材仕様を表 1 に示す．初期の目標軌道は，3 [s]で動作が完了 するものとした．このような動作の場合，リンク部材には先端の物体を水平位置まで持ち上げる際に大きな負担 が掛かることが予想される。ここでは，降伏危険性判定レベルと抑制目標レベルの相違による変化について調べ るとともに，部材剛性や動作速度の相違による変化についても検証を行うため，以下の 5 つのケースについて動 作計画を実施した。ここで, Newmark の $\beta$ 法の $\beta$ は $1 / 4$ とし，いずれの解析でも時間増分 $\Delta t$ を $0.01[\mathrm{~s}]$ とした。

Case A: $k_{y c}=5.0 \times 10^{-4}, k_{U}=0.6$

Case B: $k_{y c}=3.0 \times 10^{-4}, k_{U}=0.6$

Case C: $k_{y c}=5.0 \times 10^{-4}, k_{U}=0.4$

Case D: Case A と同じ条件で Link 3 を低剛性部材とした場合

Case E: Case A と同じ条件で低速動作とした場合

なお，安全率を高めに含むよう，ここでは降伏危険性判定レベル $k_{y c}$ を小さく設定している.

図 5 にCase A の場合の最終軌道，全リンク部材の降伏関数值の推移，全ひずみエネルギーの推移を示す．図 




Fig. 4 Lift-up motion of a robotic arm

Table 1 Specifications of the robotic arm

\begin{tabular}{|c|c|c|c|c|}
\hline & Link 1 & Link 2 & Link 3 & $\begin{array}{c}\text { Link 3 } \\
(\text { Case D) }\end{array}$ \\
\hline Material & Aluminum & Aluminum & Aluminum & Aluminum \\
\hline Link length [m] & 0.2 & 0.2 & 0.2 & 0.2 \\
\hline Cross section & Regular square & Regular square & Regular square & Regular square \\
\hline Density [kg $\left./ \mathrm{m}^{3}\right]$ & $2.70 \times 10^{3}$ & $2.70 \times 10^{3}$ & $2.70 \times 10^{3}$ & $2.70 \times 10^{3}$ \\
\hline Sectional area [m $\left.{ }^{2}\right]$ & $4.00 \times 10^{-4}$ & $4.00 \times 10^{-4}$ & $2.25 \times 10^{-4}$ & $1.00 \times 10^{-4}$ \\
\hline $\begin{array}{c}\text { Young's modulus } \\
{[\mathrm{GPa}]}\end{array}$ & 70.3 & 70.3 & 70.3 & 70.3 \\
\hline Poisson's ratio & 0.345 & 0.345 & 0.345 & 0.345 \\
\hline $\begin{array}{c}\text { Moment of inertia } \\
\left.\text { of area [m }{ }^{4}\right]\end{array}$ & $1.33 \times 10^{-8}$ & $1.33 \times 10^{-8}$ & $4.22 \times 10^{-9}$ & $8.30 \times 10^{-10}$ \\
\hline $\begin{array}{c}\text { Plastic section } \\
\left.\text { modulus [m }{ }^{3}\right]\end{array}$ & $2.60 \times 10^{-8}$ & $2.60 \times 10^{-8}$ & $8.44 \times 10^{-9}$ & $2.50 \times 10^{-9}$ \\
\hline
\end{tabular}

\begin{tabular}{|c|c|c|c|}
\hline & J2 & J3 & Tip \\
\hline Mass $[\mathrm{kg}]$ & 2.0 & 1.0 & 1.0 \\
\hline
\end{tabular}




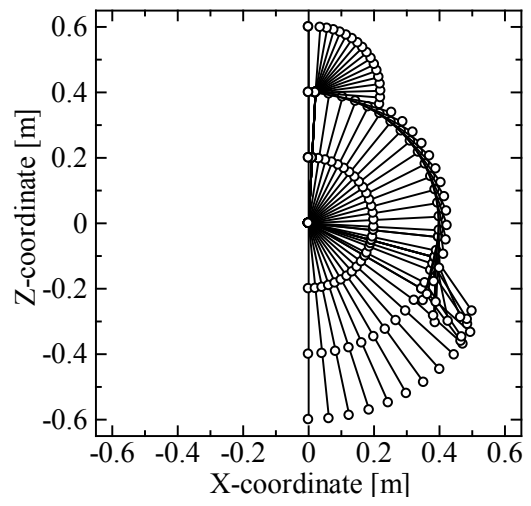

(a) Motion plan

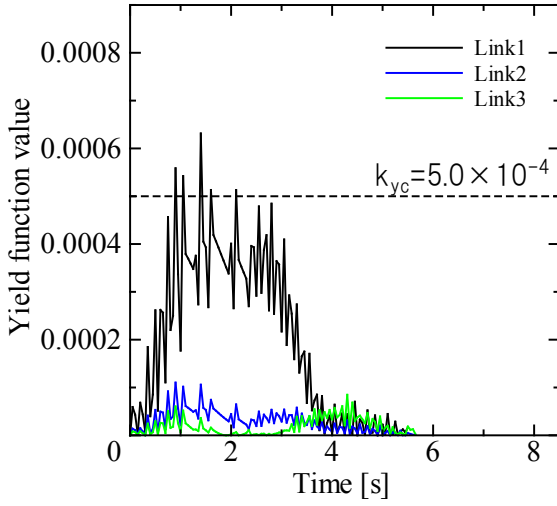

(b) Yield function values

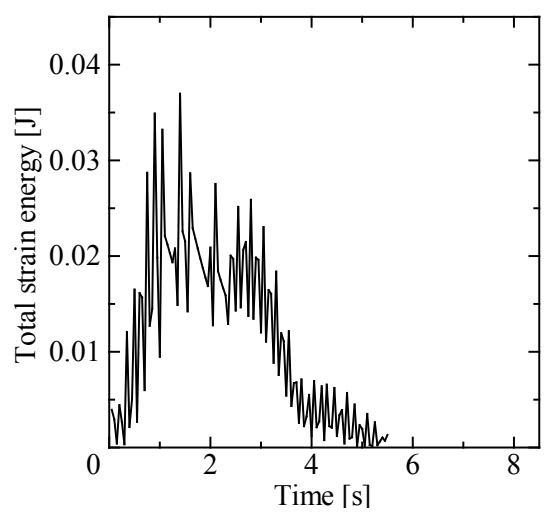

(c) Total strain energy

Fig. 5 Obtained motion plan and time histories of each structural parameter value (Case $\left.\mathrm{A},\left(k_{y c} k_{U}\right)=\left(5.0 \times 10^{-4}, 0.6\right)\right)$

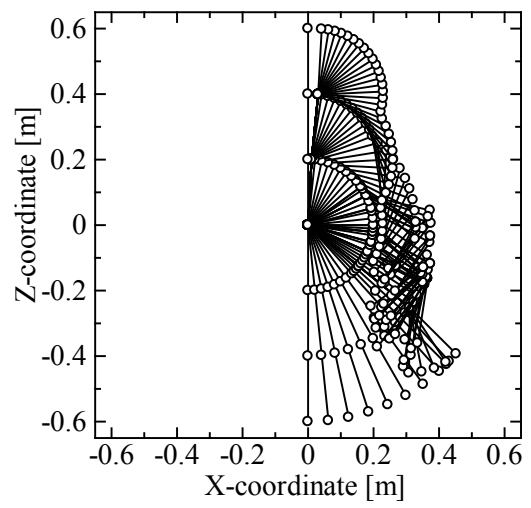

(a) Motion plan

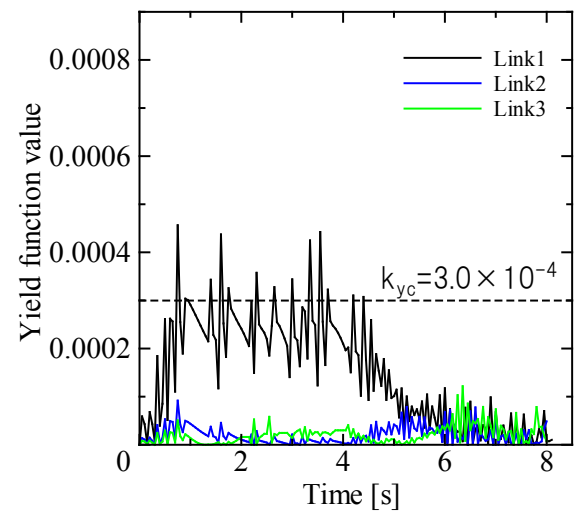

(b) Yield function values

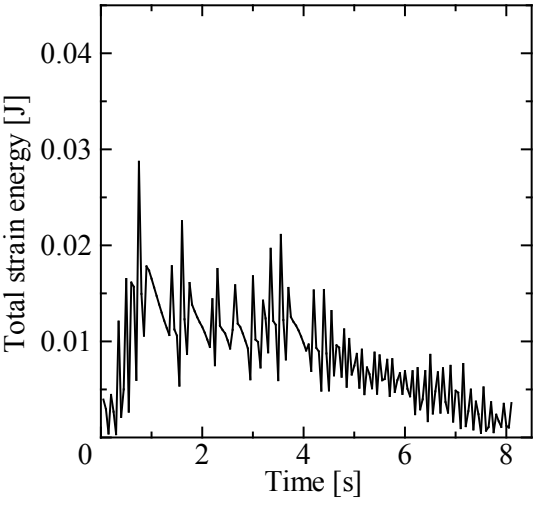

(c) Total strain energy

Fig. 6 Obtained motion plan and time histories of each structural parameter value $\left(\right.$ Case $\left.\mathrm{B},\left(k_{y c}, k_{U}\right)=\left(3.0 \times 10^{-4}, 0.6\right)\right)$

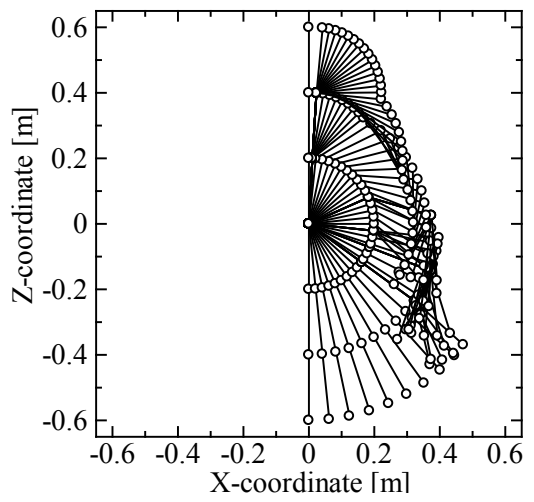

(a) Motion plan

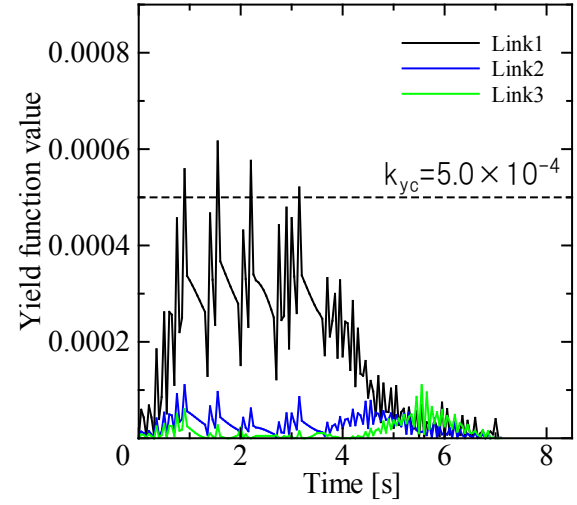

(b) Yield function values

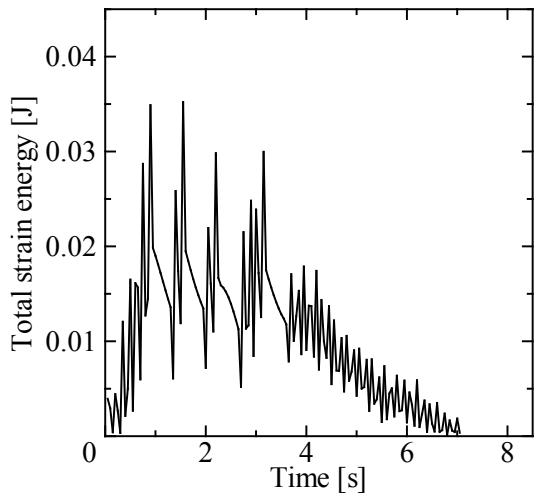

(c) Total strain energy

Fig. 7 Obtained motion plan and time histories of each structural parameter value $\left(\right.$ Case $\left.C,\left(k_{y c} k_{U}\right)=\left(5.0 \times 10^{-4}, 0.4\right)\right)$

5(a)より，動作途中で Link 3 が下向きに折り畳まれ，最終目標地点で再び伸ばされるような軌道が得られている ことが分かる，これはすなわち，アームの位置が水平に近づくにつれて根元のリンク（Link 1）の降伏関数值が 大幅に増加し，動作開始後 0.9 [s]に降伏危険性判定レベルを超え（図 5(b)参照），その後全ひずみエネルギーの 抑制が図られている (図 5(c)参照) ためである. なお, Link 2 およびLink 3 の降伏関数值は終始小さめの值で推 移しており，危険性判定の対象とはなっていないことが分かる。また，1 ステップ中に降伏関数值が急激に増加 するために，時折 $k_{y c}$ の值を関数值が大幅に超えている様子が見られる。これは，系の固有周期に対し時間増分が 粗いと見られる現象であり，時間増分を細かくすることで低減させることは可能である。しかし，実用性を追求 する上で計算時間が大幅に増加することは避けたい. 系全体の固有振動数が約 12 [Hz]であったため，ここでは時 間増分を波形が十分に追える程度の $0.01[\mathrm{~s}]$ に設定した. 


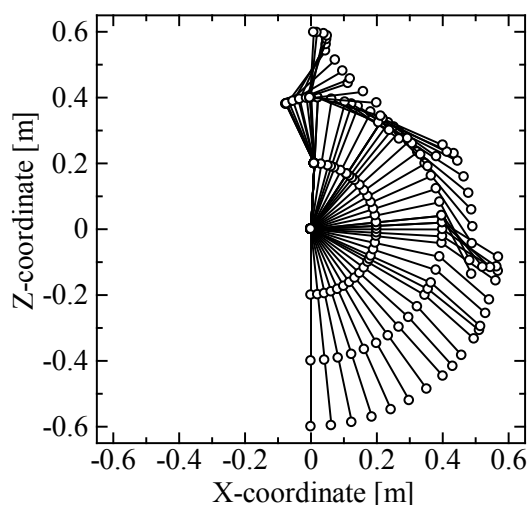

(a) Motion plan



(b) Yield function values

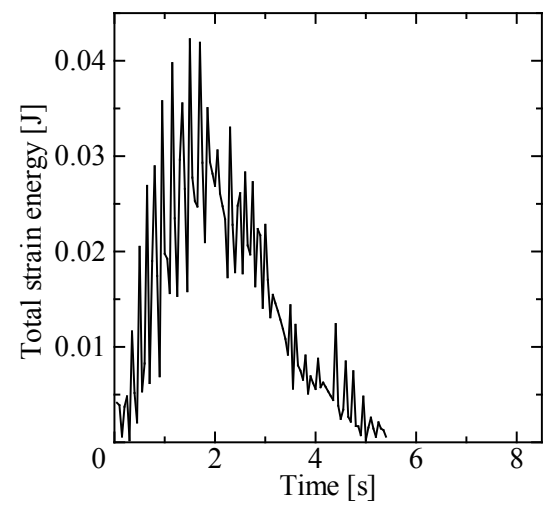

(c) Total strain energy

Fig. 8 Obtained motion plan and time histories of each structural parameter value

(Case D, where flexible member is used for Link $3,\left(k_{y c}, k_{U}\right)=\left(5.0 \times 10^{-4}, 0.6\right)$ )

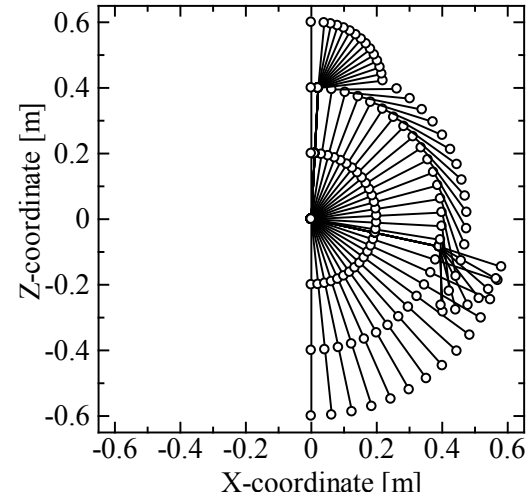

(a) Motion plan

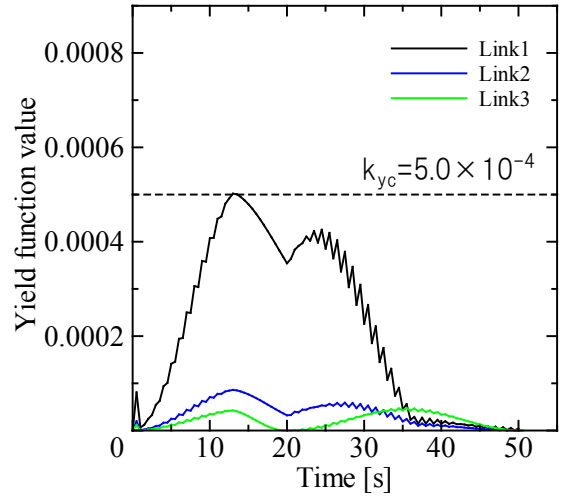

(b) Yield function values

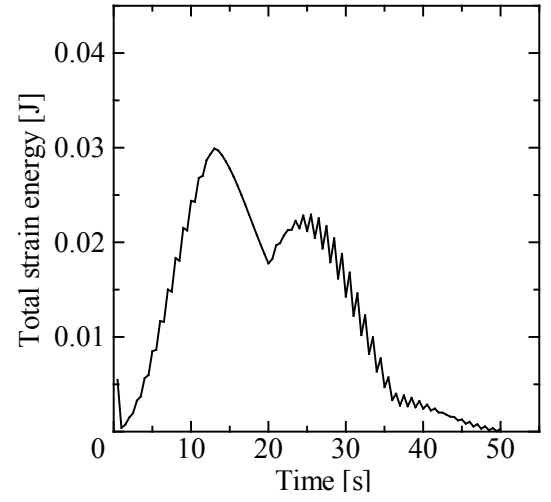

(c) Total strain energy

Fig. 9 Obtained motion plan and time histories of each structural parameter value

(Case E, low velocity case, $\left.\left(k_{y c}, k_{U}\right)=\left(5.0 \times 10^{-4}, 0.6\right)\right)$

次に, 図 6 に Case B の場合の最終軌道, 全リンク部材の降伏関数值の推移, 全ひずみエネルギーの推移を示す. Case B では, Case A の場合に対し，降伏危険性判定レベルを下げている. 寸なわち，危険性が判定されやすくな っているため, 図 6(b)に示すように Case A の場合よりも早く $0.75[\mathrm{~s}]$ で危険性が判定されている. その後も全ひ ずみエネルギーの抑制には成功している（図 6(c)参照）ものの，判定レベルが厳しいために何回も危険性が判定 されている (図 6(b)参照) . 図6(a)の動作軌道から分かるように, 全ひずみエネルギーの抑制は, Link 3 だけで なく Link 2 の姿勢も変更することで実現している. このように何回も判定と抑制が繰り返されるため, 総動作時 間も約 $8[\mathrm{~s}]$ と Case Aの場合（約 5.7 [s]）よりも長くなった.

次に, 図 7 に Case C の場合の最終軌道, 全リンク部材の降伏関数值の推移, 全ひずみエネルギーの推移を示す. 全ひずみエネルギーの抑制目標レベルをCase A の場合よりも下げているため, 1 回当りの姿勢変更が大きく（図 7(a)参照），その後の危険性判定までの時間間隔が比較的長くなっていることが分かる（図 7(b)参照）．全ひずみ エネルギーは 1 回ごとに十分に抑制されていることが分かる（図 7(c)参照）.

Case A から Case C までの例題では，リンク部材として一様に同じものを用いたが，これらの場合には当然な がら，根元のリンク部材で降伏危険性が判定される傾向があった．そこで, Case D では先端リンク（Link 3）を 低剛性のものにした場合について考える. 表 1 に示すように Link 3 の断面積を約 56\%減としたために強度が落ち, Link 3 で初めに降伏危険性が判定されている（図 8(b)参照）。また, Link 3 の強度が不足しているために, 鉛直 上方の最終目標地点付近では一部の関節が最終目標角に達することができず, かつ関節 J3 の回転のみでは全ひず みエネルギー值が抑制目標レベルまで下がらなくなった。 そこで，関節 J2 が補助的に回転して姿勢が変更され， 全ひずみエネルギー值が下がることでタスクが達成された（図 8(a)参照）。導入したアルゴリズムがうまく機能 していることが確認された. 


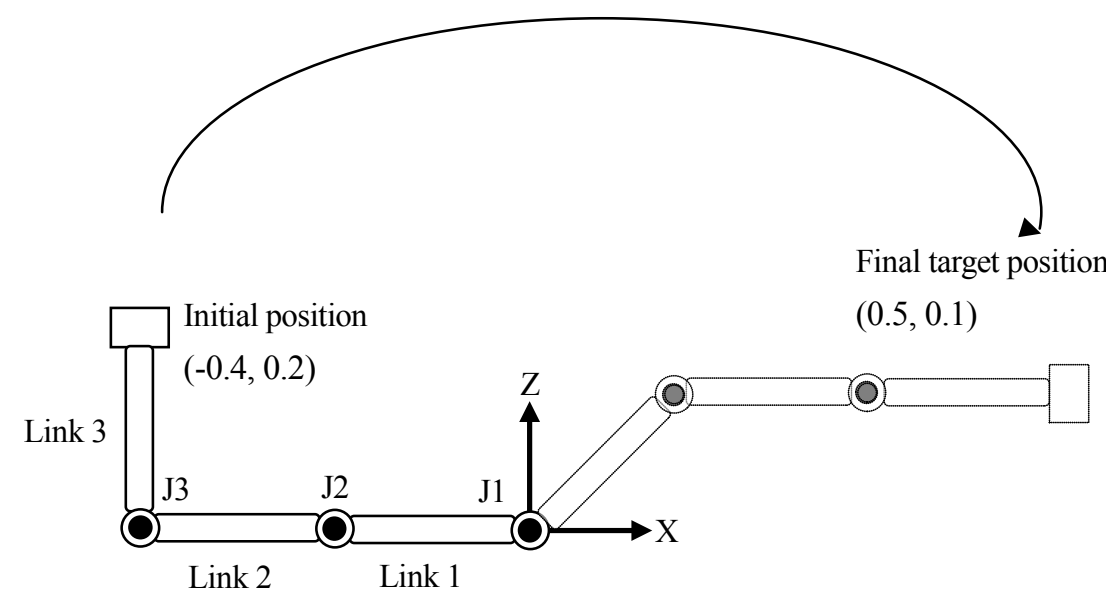

Fig. 10 Lateral carrying motion of a robotic arm

最後に，動作速度の影響を調べるために低速動作の場合について考察する．初期の目標軌道として，Case A の 場合よりも動作時間が 10 倍長い，30 [s]で動作が完了するものを与えた. 図 5 の Case A の場合と対比して図 9(a) を見ると，動作の比較的遅い段階で姿勢変更が行われていることが分かる．これは，低速動作のために慣性項が 相対的に小さく，断面力が早い段階で大きくならなかったためである. 降伏関数值（図 9(b)参照）および全ひず みエネルギー（図 9(c)参照）の滑らかな推移からも，動作速度による相違が確認できる.

以上の結果より，降伏危険性レベルや抑制目標レベルの差異により最終軌道が変化し，タスクの達成に要する 時間も変化することが確認された．また，低剛性の部材を用いた場合にも効率良く姿勢を変更し，タスクの達成 が可能な軌道を描くことが確認された。さらに，動作速度による慣性項の影響の差異も確認できた。

\section{$4 \cdot 2$ 水平持ち運び動作への適用例}

本節では，前節と同様のロボットアームを用い（ただし，先端には $30[\mathrm{~kg}]$ 質量を付加），水平持ち運び動作 を行う. その初期軌道の概要を図 10 に示す. 初期の目標軌道は, 4 [s]で動作が完了するものとした. このような 動作では, リンク部材には最終目標地点付近で最も過大な負担が掛かるため, タスクの達成がより困難となるこ とが予想される．なお，ここでは実用性の検証も行うために降伏危険性判定レベル $k_{y c}$ を大きめに設定している.

図 11 に動作計画を適用しない場合の最終軌道, 全リンク部材の降伏関数值の推移, 全ひずみエネルギーの推 移を示寸. 図 11(a)より, 慣性項の影響でリンク部材が変形している様子が観察できる.また, 図 11(b)より, 動 作の後半にかけて全てのリンク部材の降伏関数值が大幅に増大していることが分かる. この直後にLink 1 の降伏 関数值が 1 を超え（すなわち，理論的には部材が破損する）, 自動的に動作軌道の計算が止まったため, アーム 先端が最終目標地点に到達することはなかった。 図11(c)から分かるように, 系内に蓄積される全ひずみエネルギ 一も $100[\mathrm{~J}]$ を超えるような大きな数值となった.

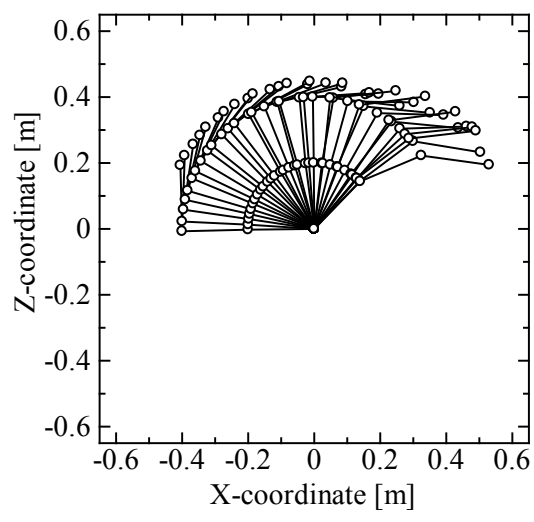

(a) Motion plan

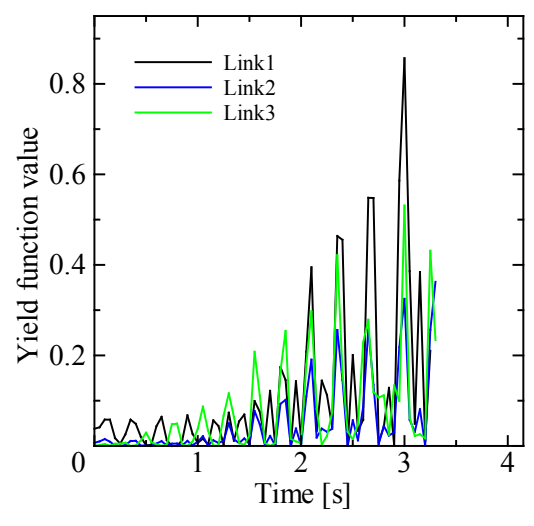

(b) Yield function value of each link



(c) Total strain energy

Fig. 11 Motion and time histories of each structural parameter value for lateral carrying motion when planning is not applied 


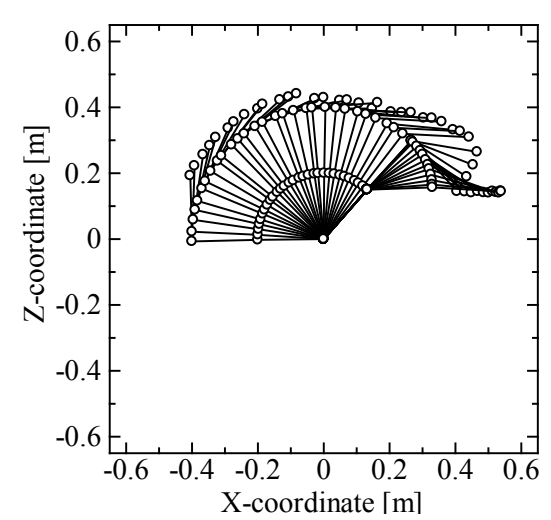

(a) Motion plan



(b) Yield function value of each link

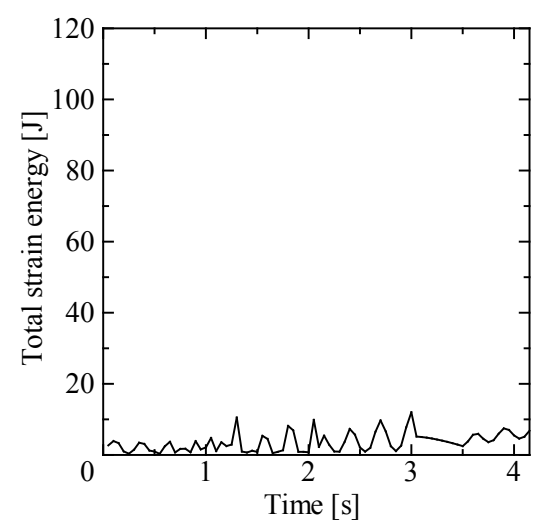

(c) Total strain energy

Fig. 12 Obtained motion plan and time histories of each structural parameter value for lateral carrying motion

$$
\left(\left(k_{y c} k_{U}\right)=(0.1,0.3)\right)
$$

図 12 に動作計画を適用した場合の最終軌道，全リンク部材の降伏関数值の推移，全ひずみエネルギーの推移 を示す．ここでは，降伏危険性判定レベル $k_{y c}$ を $0.1 ，$ 抑制目標レベル $k_{U} を 0.3$ と設定している．図 $12(\mathrm{a})$ に見られ るように, 動作後半でLink 3 を折り畳むような軌道が作成され，その後アームを最終目標地点まで伸ばす形でタ スクが達成できている．図 12(b)より，どのリンクも概ね同じような降伏関数值の推移を見せるが，1.3 [s]に Link 3 で初めて降伏危険性が判定されている. 図 11(c)と比較すると, 全ひずタエネルギーは概ね 1 割程度に抑制され ていることが分かる（図 12(c)参照）。

以上の結果より，降伏危険判定レベルを実用的な值に引き上げ，リンク部材の強度を最大限に利用した持ち運 び動作においても，提案した動作計画法が有効に機能することが確認された.

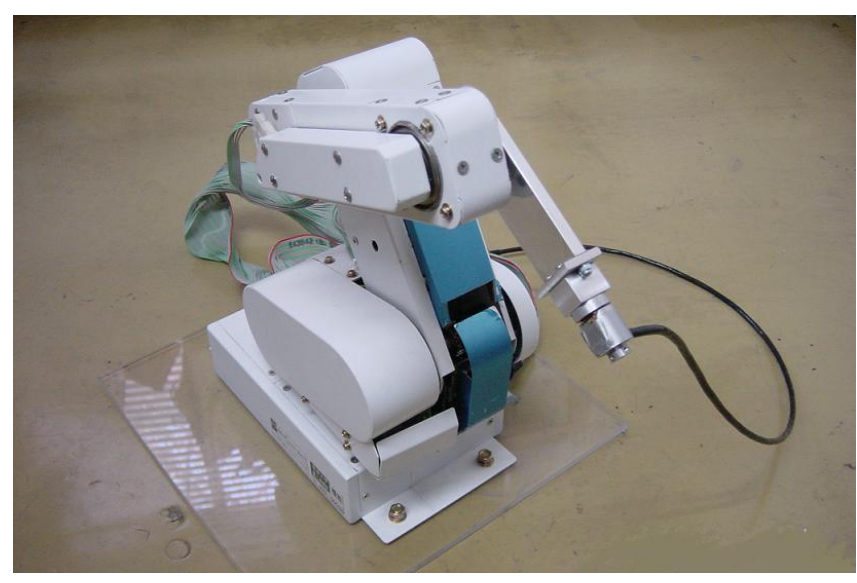

Fig. 13 Robotic arm used in experiments (Dengineer DRA-302A)

\section{5. 実機への搭載と検証}

本章では，提案した動作計画法を実際のロボットアームに搭載し，検証した結果について記す. 図 13 に示すロ ボットアーム（デンジニア社製 DRA-302A 型）の先端に 6 軸力覚センサ（BL_AUTOTEC 社 MICRO5/50）を設置 し, 先端に $0.2[\mathrm{~kg}]$ の錘を取り付けた. 表 2 にロボットアームの仕様を, 表 3 に力覚センサの仕様を示す.アーム の仕様は主にカタログデータから抽出したが, 断面形状など詳細が分からないものについては外形から推定した. アームに実装されているエンコーダおよび力覚センサからの情報は $0.1[\mathrm{~s}]$ ごとに検出した. また，降伏危険性判 定レベル $k_{y c}$ を $7.0 \times 10^{-6}$ ，抑制目標レベル $k_{U}$ を 0.8 と設定した.

図 14 に実験に用いた初期軌道の概形を示す.これを動作計画法に入力し，その出力結果に基づきアームをリア ルタイムで動作させた. 図 15 にアームの動作の様子を, 図 16 に根元のリンク（Link 1）の降伏関数值の推移お よび全ひずみエネルギーの推移を示す.アームを水平方向へ伸ばし始めた $2.5[\mathrm{~s}]$ の時点で降伏危険性が判定され, 
Table 2 Spec of the robotic arm (Dengineer DRA-302A)

\begin{tabular}{|c|c|c|c|}
\hline & Link 1 & Link 2 & Link 3 \\
\hline Material & Aluminum & Aluminum & Aluminum \\
\hline Link length [m] & 0.2 & 0.2 & 0.2 \\
\hline Cross section & Box & Box & Rectangle \\
\hline Density $\left[\mathrm{kg} / \mathrm{m}^{3}\right]$ & $2.70 \times 10^{3}$ & $2.70 \times 10^{3}$ & $2.70 \times 10^{3}$ \\
\hline Sectional area $\left[\mathrm{m}^{2}\right]$ & $2.24 \times 10^{-4}$ & $2.90 \times 10^{-4}$ & $2.40 \times 10^{-4}$ \\
\hline $\begin{array}{c}\text { Young's modulus } \\
\text { [GPa] }\end{array}$ & 70.3 & 70.3 & 70.3 \\
\hline Poisson's ratio & 0.345 & 0.345 & 0.345 \\
\hline $\begin{array}{c}\text { Moment of inertia of } \\
\text { area }\left[\mathrm{m}^{4}\right]\end{array}$ & $1.88 \times 10^{-7}$ & $1.06 \times 10^{-7}$ & $3.21 \times 10^{-6}$ \\
\hline $\begin{array}{l}\text { Plastic section } \\
\text { modulus }\left[\mathrm{m}^{3}\right]\end{array}$ & $1.01 \times 10^{-5}$ & $5.25 \times 10^{-6}$ & $2.40 \times 10^{-6}$ \\
\hline
\end{tabular}

Table 3 Spec of force sensor

\begin{tabular}{|c|c|c|}
\hline \multicolumn{2}{|c|}{ Rated load [kgf] } & 5 \\
\hline \multicolumn{2}{|c|}{ Accuracy [\%] } & 2.0 \\
\hline \multirow{2}{*}{ Resolution [gf] } & $\mathrm{F}_{\mathrm{x}}, \mathrm{F}_{\mathrm{y}}$ & 5 \\
\cline { 2 - 3 } & $\mathrm{F}_{\mathrm{z}}$ & 15 \\
\hline
\end{tabular}

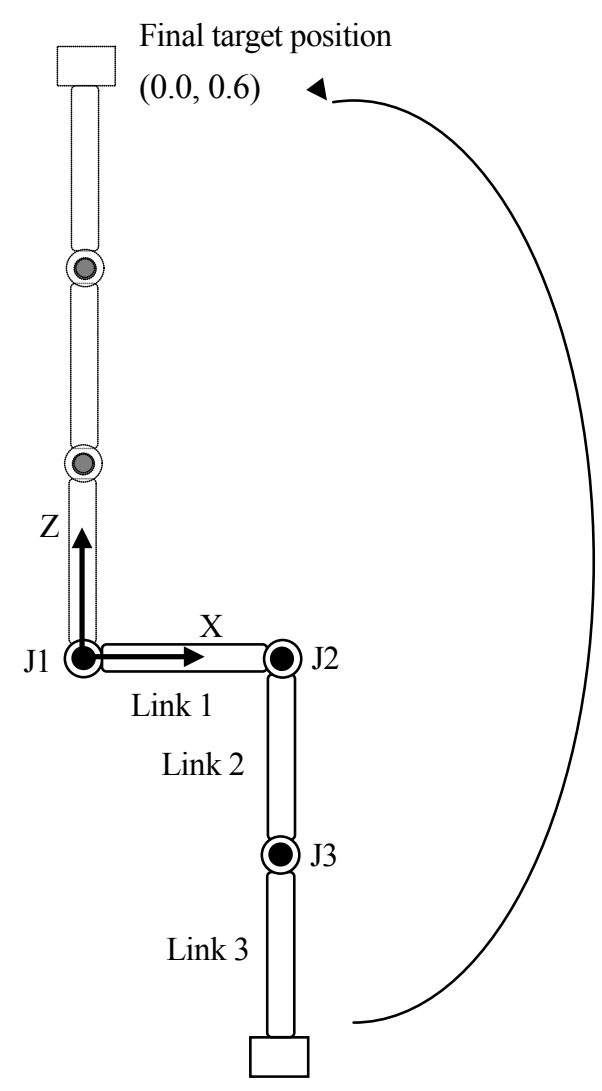

Initial position

$(0.2,-0.4)$

Fig. 14 Initial target motion for the experiment 


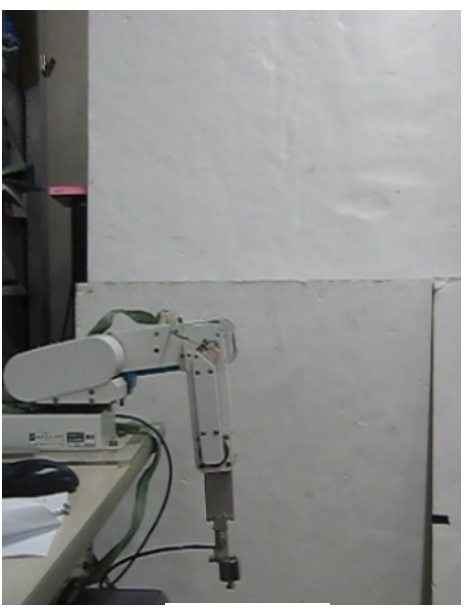

$0.0[\mathrm{~s}]$

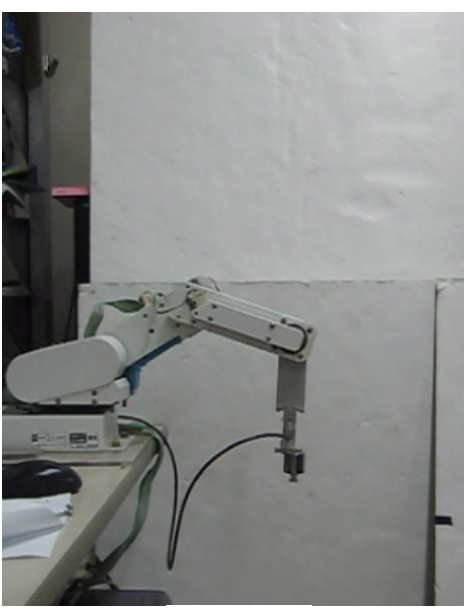

$5.7[\mathrm{~s}]$

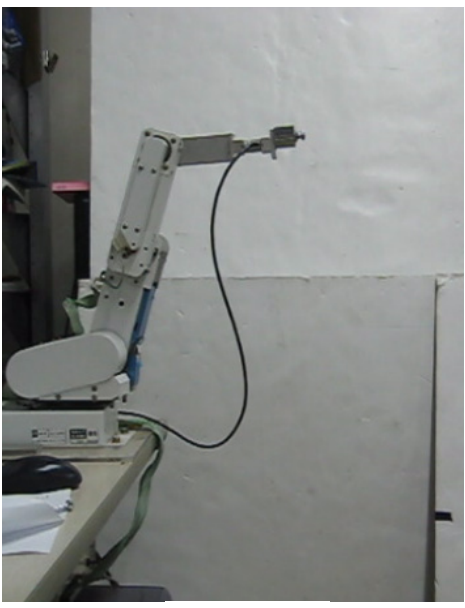

$12.5[\mathrm{~s}]$

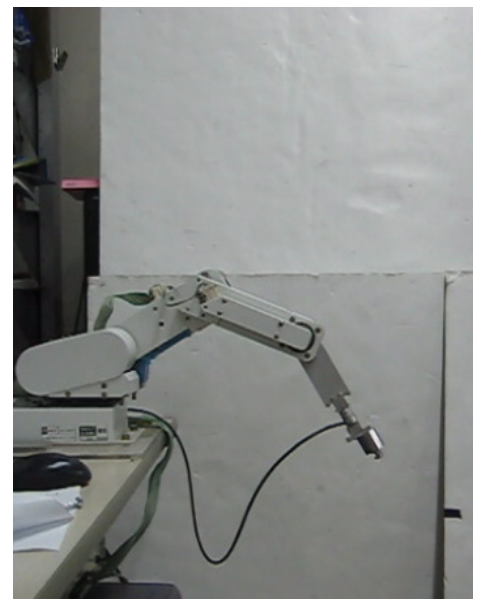

$2.5[\mathrm{~s}]$

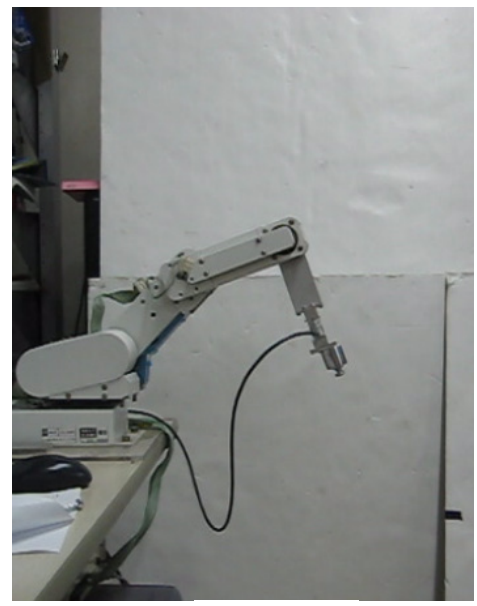

$6.5[\mathrm{~s}]$

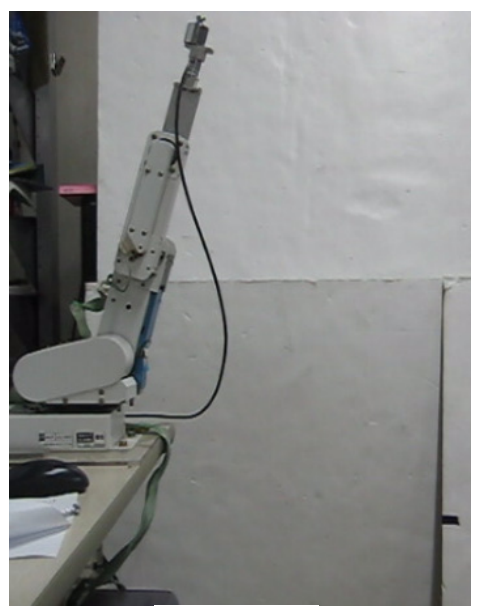

$16.0[\mathrm{~s}]$

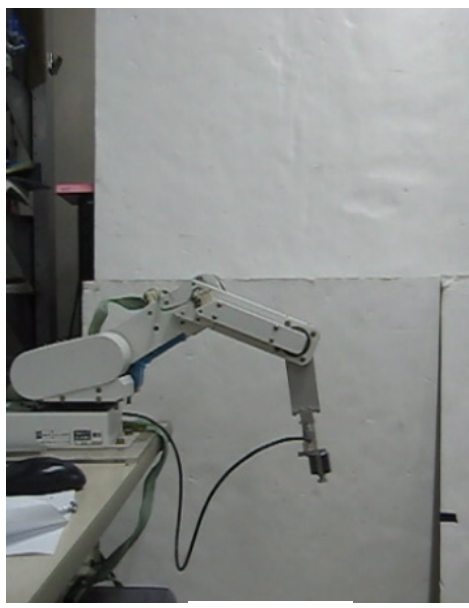

$4.0[\mathrm{~s}]$

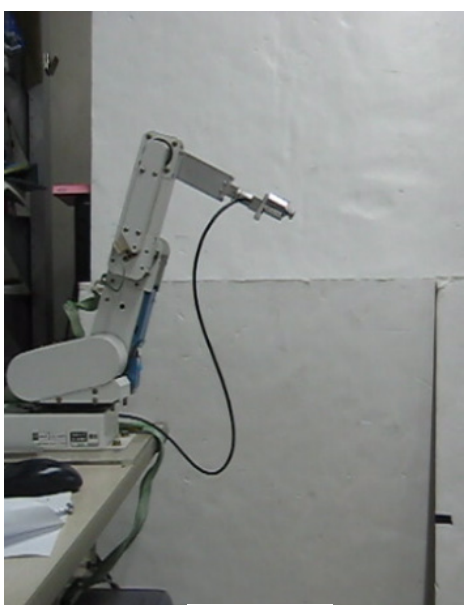

$9.8[\mathrm{~s}]$

Fig. 15 Motion obtained in the experiment

その後アームを折り畳むように姿勢を変更し，上方へ持ち上げている様子が観察できる．計 1 回しか危険性判定 は行われなかったが，図 16(b)に示すように全ひずみエネルギーも効率良く抑制され，タスクが達成できること が確認された．今回の実験では，実機の仕様の関係から時間増分が粗く，しかも部材剛性が高いリンクを使用し ていたため，慣性項を導入した動作計画法の検証を厳密に行うことは困難であった．低剛性のリンクに対し慣性 項を導入した実験については, 今後の課題としたい. 


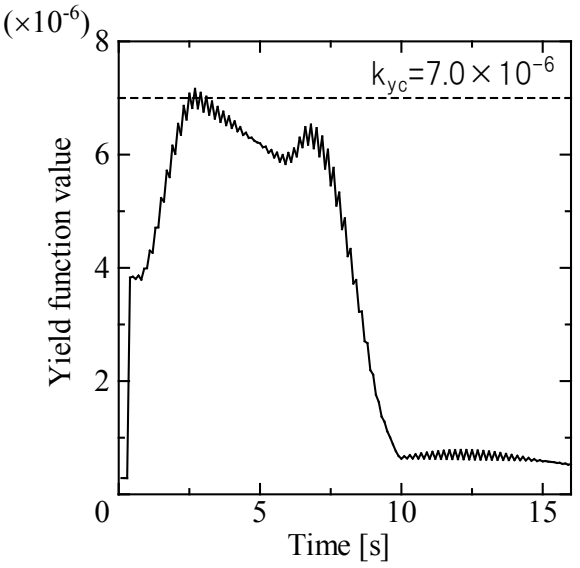

(a) Yield function value of Link 1



(b) Total strain energy

Fig. 16 Time histories of each structural parameter value obtained in the experiment $\left(\left(k_{y c}, k_{U}\right)=\left(7.0 \times 10^{-6}, 0.8\right)\right)$

\section{6. 結}

本稿では，先行研究において開発された，部材の強度的危険性を断面力レベルでの降伏関数を用いて判定し， 機構内に蓄積される全ひずみエネルギ一を抑制することで安全な姿勢を求める動作計画法に対し, 慣性項の考慮 とタスク未達成時に補助的に多くの関節を動かす過程を加えることで実用性の向上を図った口ボットアームの 鉛直持ち上げ動作および水平持ち運び動作に適用した結果，降伏危険性判定レベルおよび抑制目標レベルそれぞ れの值により動作が適切に変化する様子を確認することができた. また，慣性項導入の効果，および低剛性部材 にも対応できる実用性を確認することができた．高剛性アームが軽量物を運搬する場合には問題にならないが， 低剛性アームが重量物を運搬する場合には，降伏危険性判定レベルおよび抑制目標レベルを適切に設定し，部材 破損の回避とタスクの達成を同時に実現しなければならない.今後は，このような問題に対する適切なレベル設 定の指標を見出していく必要がある.

\section{文献}

(1) Yoshikawa, T., "Manipulability of Robotic Mechanisms”, International Journal of Robotics Research, Vol. 4 (1985), pp. 3-9.

(2) 平山 智信, 永谷 圭司, 五福 明夫, “可操作性を考慮した移動マニピュレータの動作計画”, ロボティクス・メカ トロニクス講演会, 1A1-B5, 2001.

(3) 小野 京右, 劉 栄強, “2 足歩行ロボットの最適軌道計画解 (第 1 報, 最適軌道解析法と全関節駆動系の最適解)”, 日本機械学会論文集 C 編, Vol. 67, No. 660 (2001), pp. 2601-2608.

(4) 小田 尚樹, 村上 俊之，大西 公平，“オブザーバに基づく圥長マニピュレータの局所トルク最適化”，日本機 械学会論文集 C 編, Vol. 62, No. 602(1996),pp. 3786-3792.

(5) 毛利 彰, 平野 剛, 山本 元司, “2台のマニピュレータの協調動作経路計画”, 計測自動制御学会論文集, Vol. 34, Vol. 8 (1998), pp. 935-940.

(6) 磯部 大吾郎, 石井 悠一郎, “構造強度に着目したロボット機構の姿勢決定および動作計画”, 日本ロボット学会誌, Vol. 22, No. 1 (2004), pp. 75-82.

(7) Isobe, D. and Komatsu, A., "Motion Planning of Manipulators Regarding Structural Safety as a Prior Condition", Advanced Robotics, Vol.21, No.5 (2007), pp. 533-554.

(8) 磯部 大吾郎, 今泉 大作, “リンク系の部材剛性に依存しない統一的逆動力学計算法”, 日本機械学会論文集 C 編, Vol. 70, No. 691 (2004), pp. 728-735.

(9) 磯部 大吾郎, 加藤 昭博, “フレキシブル・リンク系のモデルベースド・フィードフォワード制御”, 日本ロボット 学会誌, Vol. 25, No. 4 (2007), pp. 625-631.

(10) Bathe, K.J., Finite Element Procedures, Prentice-Hall, (1996). 